\title{
A potential groundwater aquifer for palaeoclimate reconstruction: Turonian aquifer, Tadla basin, Morocco
}

\author{
Radouan Saadi ${ }^{\mathrm{a}}$, Marianna Túrib, c, *, László Palcsu ${ }^{\mathrm{b}}$, Hamid Marah ${ }^{\mathrm{a}}$, Oum Keltoum Hakam ${ }^{\mathrm{d}}$, László Rinyu ${ }^{\mathrm{b}}$, \\ Mihály Molnár ${ }^{\mathrm{b}}$, István Futób \\ a Centre National de l'Energie, des Sciences et Techniques Nucleaires (CNESTEN), 65 rue Tansift, Agdal, Rabat, Morocco \\ ${ }^{\mathrm{b}}$ Isotope Climatology and Environmental Research Centre (ICER), Institute for Nuclear Research, Hungarian Academy of Sciences, Bem tér 18/C, 4026 Debrecen, Hungary \\ ${ }^{c}$ Department of Mineralogy and Geology, University of Debrecen, Egyetem tér 1, 4010 Debrecen, Hungary \\ ${ }^{\mathrm{d}}$ Department of Physics, Ibn Tofail University, B.P 133, 14000 Kenitra, Morocco
}

\section{A R T I C L E IN F O}

\section{Article history:}

Received 26 October 2016

Received in revised form 7 April 2017

Accepted 20 April 2017

Available online $\mathrm{xxx}$

Keywords:

Oxygen isotope ratio

Hydrogen isotope ratio

Carbon isotope ratio

Noble gas (He, Ne, Ar, Kr, Xe)

${ }^{14} \mathrm{C}$

Turonian aquifer

Tadla basin Morocco

\begin{abstract}
A B S T R A C T
We undertook an environmental isotope investigation of groundwater from the Turonian Aquifer of Tadla Basin in Morocco in order to confirm that this aquifer could be a potential site for palaeoclimate reconstruction. The collected groundwater samples were examined for stable oxygen, hydrogen and carbon isotope ratio, as well as noble gases ( $\mathrm{He}, \mathrm{Ne}, \mathrm{Ar}, \mathrm{Kr}, \mathrm{Xe}),{ }^{14} \mathrm{C}$ and ${ }^{3} \mathrm{H}$ concentration. The measured stable oxygen and hydrogen isotope values show that the Turonian aquifer has two recharge areas, one with a heavier isotopic signature from the unconfined aquifer in the northern region (the area of Boujad), while the other is characterised by lighter isotopic composition in the north-eastern to the south-western part of the basin (to the North from Kasba Tadla). The calculated noble-gas solubility temperatures of the confined part of the aquifer are $2{ }^{\circ} \mathrm{C}$ higher than the recent mean annual air temperature $\left(19^{\circ} \mathrm{C}\right)$. Radiocarbon ages obtained from running different versions of Ingerson-Pearson models indicated that the recharge of this water occurred during the Holocene. We conclude that the Turonian aquifer might be a potential place for Late-Pleistocene palaeoclimate reconstruction if the research area were extended in the direct of flow path towards the western part of the basin and towards the foothills of the Phosphates Plateau.
\end{abstract}

(C) 2016 Published by Elsevier Ltd.

\section{Introduction}

Groundwater has long been recognized as a useful archive for quantitative palaeoclimate reconstructions. Environmental studies with high resolution proxy data are essential in understanding the past and present climate. The analysis of environmental isotopes, tracers and noble gases associated with climate conditions is a powerful method for climate reconstruction.

Although Africa is a huge continent, past climate studies based on reconstruction of groundwater recharge temperatures are scarce (Rudolph et al., 1984; Heaton et al., 1986; Darling et al., 1987; Fontes et al., 1993; Kulongoski et al., 2004; Bakari et al., 2012; Abouelmagd et al., 2014). We have designed a preliminary study to reconstruct the recharge condition of the groundwater in the Turonian aquifer, Tadla Basin, Morocco, based on the investigation of noble gas concentrations, stable isotopes, tritium, and radiocarbon content. It has been shown previously that there is a strong connection between the surface temperature and the oxygen or hydrogen isotope ratios of precipitation (Dansgaard, 1964; Rozanski et al., 1993). This relation plays a major role in palaeoclimate reconstructions due to the

\footnotetext{
* Corresponding author. Isotope Climatology and Environmental Research Centre (ICER), Institute for Nuclear Research, Hungarian Academy of Sciences, Bem tér 18/ C, 4026 Debrecen, Hungary
}

Email address: turi.marianna@atomki.mta.hu (M. Túri) preservation of isotopic signals in a groundwater system during recharge. The noble gases have similar attributes, because the dissolved atmospheric noble gas concentrations in the groundwater do not change along the flow path, as they do not take part in any chemical or biological processes. From dissolved noble gas concentrations, the recharge temperature (noble gas temperature: NGT) of the groundwater can be determined due to the temperature-dependent gas solubility in water. These temperatures, combined with groundwater dating, are a useful tool for paleoclimatic reconstruction (Stute and Schlosser, 1993; Aeschbach-Hertig et al., 1999; Klump et al., 2008; Varsányi et al., 2011). The purpose of this investigation is to analyse the recharge conditions of the samples in boreholes using stable isotopes, noble gas temperatures, and water age determinations. Preliminary results of Bouchaou et al. (2009) and the IAEA (Marah et al., 2010) in the area have provided some basic information about the groundwater conditions in the area. Bouchaou et al. (2009) have provided a comprehensive analysis of water resources in the four main aquifers of the Tadla basin using geochemical and isotope tracers. The Liassic aquifer and the Turonian aquifer constitute the main water resources in Morocco. The isotope studies have shown that the Turonian aquifer is composed of young, recharging water from the North-Northeastern part of the basin, and old waters in the Tassaout area to the Southwest. However, the work of Bouchaou et al. ( 2009) argued the age distribution of the aquifer systems, and was not concerned in term of palaeoclimate reconstruction. Here, we have made 
the first attempt to determine noble gas solubility temperatures of groundwaters in this region, to reveal past recharge temperatures. The main goal of our study is to determine that the Turonian aquifer is suitable for further palaeoclimate investigations with respect to Last Glacial Maximum (LGM) and eventually to study the temperature difference between the Holocene and the late Pleistocene.

\section{Description of the study area}

The Tadla basin $\left(5000 \mathrm{~km}^{2}\right)$ is located in central Morocco in a vast syncline, which has a multi-layer aquifer system. Part of this basin is the multi-layer aquifer system of the Oum Er-Rabia basin is composed of four main superposed aquifers. They are, from shallower to deeper, the Mio-Plio-Quaternary, the Maastrichtian-Eocene, the Senonian and the Turonian (Misdaq and Eiharti, 1997; Ettazarini and Mahmouhi, 2004). These geological formations consist of permeable conglomerates, karstic limestones, marls and phosphate sandstones and from semi-permeable to impermeable clayey and marly layers (Hsissou et al., 1996; Ettazarini, 2006; Bouchaou et al., 2009). The Turonian aquifer, which is the focus of interest in our study, is the main productive aquifer of the Moroccan hydrogeological basin of Oum Er-Rabia. It extends in ENE-WSW direction between the Phosphates Plateau and the High Atlas of Beni-Mellal in the Oum Er-Rabia River watershed (see Fig. 1). The climate of the region is a warm temperate zone with hot and dry summers (Peel et al., 2007). The annual temperature is about $19^{\circ} \mathrm{C}$ (GeoModel Solar2010-2015). The soil type in the area of the outcrop zone and of the Tadla basin is chromic luvisols, with a reddish hue and haplic valcisols including a significant accumulation of calcium carbonates (Jones et al., 2013). The Turonian aquifer is composed of limestone and karstic dolomite, and it is interlayered with marly horizons (Ettazarini, 2004). The thickness ranges from $50 \mathrm{~m}$ in the north to $100 \mathrm{~m}$ in the south (Fig. 1). A piezometric survey of deep aquifers, mostly in the Turonian aquifer, shows a flow direction from the north to the south and southwest, towards the centre of the basin (Fig. 1) (Ettazarini, 2004, 2006; Tammal et al., 2014).

\section{Sample collection and measurements}

Seventeen groundwater samples were collected for ${ }^{3} \mathrm{H},{ }^{14} \mathrm{C}$, stable oxygen, hydrogen and carbon analyses, and ten samples were taken for noble gas ( $\mathrm{He}, \mathrm{Ne}, \mathrm{Ar}, \mathrm{Kr}, \mathrm{Xe}$ ) analyses. The samples were col-

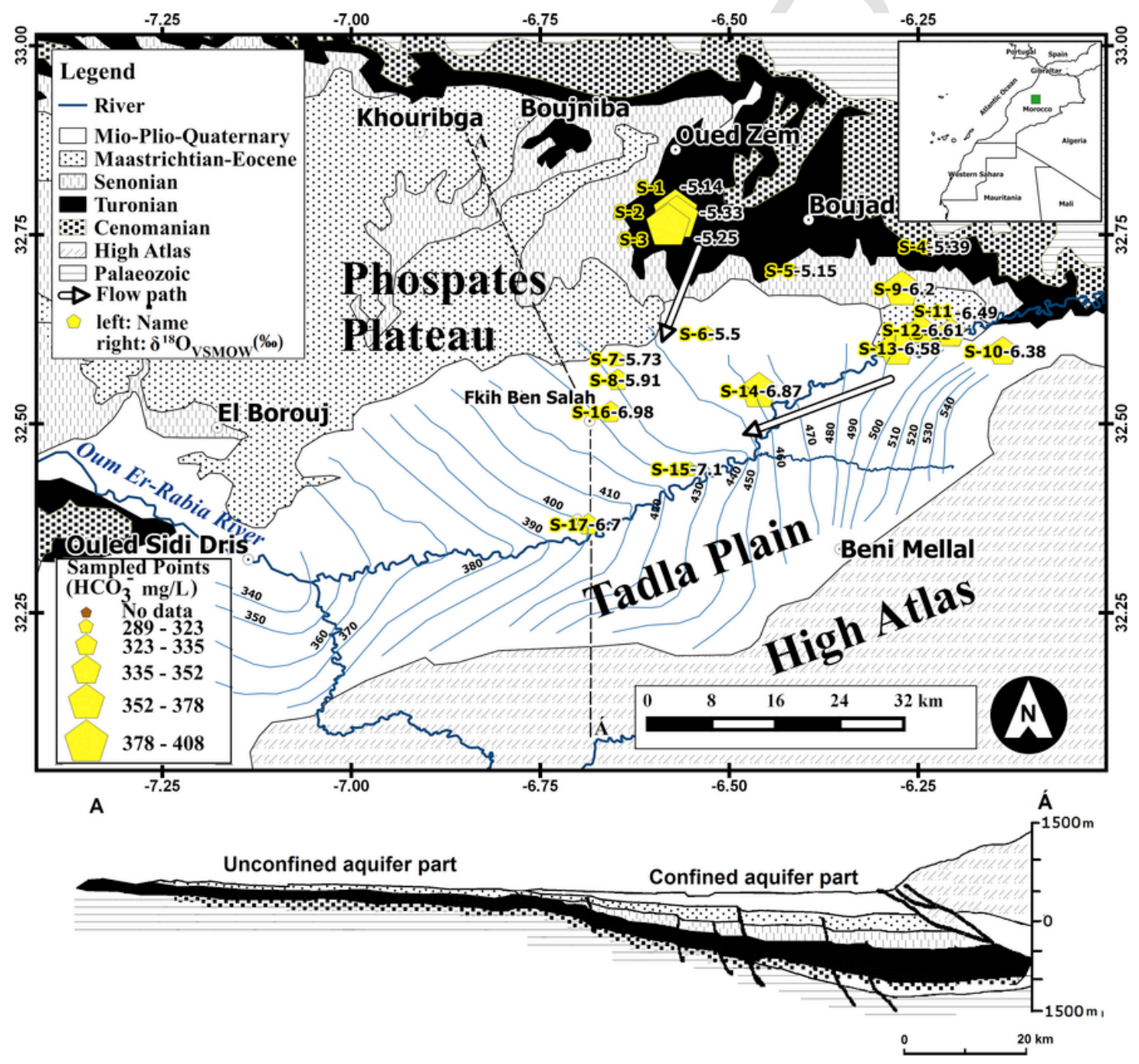

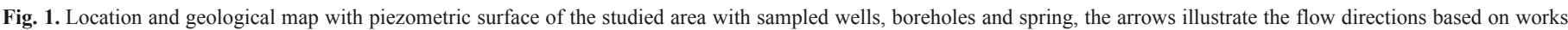

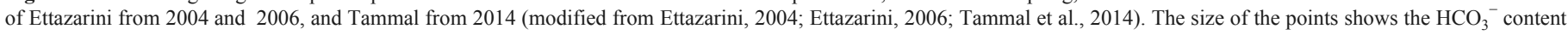
$(\mathrm{mg} / \mathrm{L})$ of the sampled points with labels where the left represents the name and the right means the oxygen isotope ratio of the water. 
lected from artesian boreholes, wells and a spring (Fig. 1). In situ pH, alkalinity, temperature and electrical conductivity measurements were carried out after pumping out three times the volume of each well in order to obtain representative groundwater circulating at deep levels (Table 1).

Stable isotopes of oxygen and hydrogen as well as ${ }^{3} \mathrm{H}$ (tritium) were analysed in the Centre National de l'Energie, des Sciences et Techniques Nucléaires (CNESTEN), Rabat, Morocco (CNESTEN). The results of stable isotope studies are expressed in the conventional $\delta$ notation in \%o versus V-SMOW with a reproducibility of $\pm 0.1 \%$ for $\delta^{18} \mathrm{O}$ and $\pm 1 \%$ for $\delta^{2} \mathrm{H}$. Following the equation: $\delta=$ $\left(\mathrm{R}_{\text {sample }} / \mathrm{R}_{\text {standard }}-1\right) * 1000$, where $\mathrm{R}$ is the ${ }^{2} \mathrm{H} / \mathrm{H},{ }^{18} \mathrm{O} /{ }^{16} \mathrm{O}$ ratio in the sample or in the international standard. The ${ }^{3} \mathrm{H}$ contents were analysed using liquid scintillation spectrometer after electrolytic enrichment and results are expressed in Tritium Units (TU) (Marah, 2007). The detection limit and the precision of the tritium measurements was 0.5 TU.

The carbon isotopes of the dissolved inorganic carbon were measured by a ThermoFinnigan Delta ${ }^{\text {PLUS }}$ XP isotope ratio mass spectrometer in online mode, attached to an automated GASBENCH II sample preparation device (Vodila et al., 2011). The results are expressed as $\delta^{13} \mathrm{C}$ in $\delta$ notation in \%o versus VPDB and precision is $\pm 0.1 \%$.

The measurement of ${ }^{14} \mathrm{C}$ (radiocarbon) of the dissolved inorganic carbon in water samples was carried out with an EnvironMICADAS accelerator mass spectrometer (AMS). The extractions of $\mathrm{CO}_{2}$ were performed by the addition of $85 \%$ phosphoric acid in a vacuum line, and then the released $\mathrm{CO}_{2}$ was cryogenically purified and trapped (Molnár et al., 2013a, 2013c). The extracted pure $\mathrm{CO}_{2}$ gas was transformed to graphite by a sealed tube graphitization method (Rinyu et al., 2013). The resulting graphite targets were measured for ${ }^{14} \mathrm{C} /{ }^{12} \mathrm{C}$ by AMS (Molnár et al., 2013b). The uncertainty of measurements were below $0.5 \%$ for each sample, including normalization, background subtraction, and counting statistics. ${ }^{14} \mathrm{C}$ results are reported as percent modern carbon (pMC).

Groundwater samples for noble gas analysis were taken into copper tubes (Stute and Schlosser, 1993). The determination of noble gas isotope ratios and concentrations was performed by a VG5400 noble gas mass spectrometer (Palcsu et al., 2010; Papp et al., 2012). The groundwater samples for noble gas measurements are passed through

Table 1

Chemical parameters $\left(\mathrm{T}=\right.$ temperature in ${ }^{\circ} \mathrm{C} ; \mathrm{EC}=$ electrical conductivity in $\mu \mathrm{S} / \mathrm{cm}$; $\mathrm{pH})$ and stable oxygen $\left(\delta^{18} \mathrm{O}\right.$ in \% VSMOW) and hydrogen $\left(\delta^{2} \mathrm{H}\right.$ in \%o VSMOW) isotope composition of the groundwater samples with their nature and screen depth $($ depth $=$ the screen depth in meters below surface, screen depth above sea level in $\mathrm{m}$ ).

\begin{tabular}{|c|c|c|c|c|c|c|c|c|}
\hline Name & $\begin{array}{l}\text { Depth } \\
\text { (m) }\end{array}$ & $\begin{array}{l}\text { Screen depth } \\
\text { above sea } \\
\text { level }(\mathrm{m})\end{array}$ & Type & $\begin{array}{l}\mathrm{T} \\
\left({ }^{\circ} \mathrm{C}\right)\end{array}$ & $\begin{array}{l}\mathrm{EC} \\
(\mu \mathrm{S} / \\
\mathrm{cm})\end{array}$ & $\mathrm{pH}$ & $\begin{array}{l}\delta^{18} \mathrm{O} \\
(\% \mathrm{o})\end{array}$ & $\begin{array}{l}\delta^{2} \mathrm{H} \\
(\% 0)\end{array}$ \\
\hline S-01 & 30 & 632 & Well & 24.6 & 1172 & 7.37 & -5.14 & -32.6 \\
\hline S-02 & - & 639 & Spring & 23.1 & 1216 & 7.25 & -5.33 & -32.8 \\
\hline S-03 & 45 & 609 & Well & 23.4 & 1180 & 7.42 & -5.25 & -30.8 \\
\hline S-04 & 17 & 624 & Well & 23.0 & 768 & 7.69 & -5.39 & -35.6 \\
\hline S-05 & 85 & 513 & Borehole & 24.2 & 1260 & 7.53 & -5.15 & -33.9 \\
\hline S-06 & 180 & 329 & Borehole & 26.6 & 1057 & 7.32 & -5.50 & -31.8 \\
\hline S-07 & 228 & 256 & Borehole & 25.8 & 850 & 7.24 & -5.73 & -33.5 \\
\hline S-08 & 300 & 169 & Borehole & 24.8 & 1120 & 7.28 & -5.91 & -33.6 \\
\hline S-09 & 100 & 483 & Borehole & 27.9 & 620 & 7.51 & -6.20 & -37.0 \\
\hline S-10 & 200 & 386 & Borehole & 26.9 & 708 & 7.07 & -6.38 & -38.5 \\
\hline S-11 & 150 & 351 & Borehole & 22.8 & 1365 & 7.40 & -6.49 & -39.9 \\
\hline S-12 & 100 & 442 & Borehole & 24.4 & 1260 & 7.57 & -6.61 & -44.3 \\
\hline S-13 & 236 & 268 & Borehole & 23.5 & 1163 & 7.35 & -6.58 & -39.9 \\
\hline S-14 & 330 & 149 & Borehole & 30.0 & 890 & 7.39 & -6.87 & -41.1 \\
\hline S-15 & 604 & -169 & Artesian & 40.3 & 1620 & 7.44 & -7.10 & -36.9 \\
\hline S-16 & 390 & 58 & Borehole & 36.5 & 1160 & 7.00 & -6.98 & -39.4 \\
\hline S-17 & 480 & -71 & Artesian & 35.8 & 812 & 7.10 & -6.70 & -36.1 \\
\hline
\end{tabular}

a gas extraction and purification system to trap water vapour and chemically active gases. After purification and separation, the helium, neon, and the argon-krypton-xenon fractions were sequentially admitted into the noble gas mass spectrometer. The precision of measurements for the helium and argon fraction was less than $1 \%$ and less than $2 \%$ for $\mathrm{Ne}, \mathrm{Kr}, \mathrm{Xe}$ concentrations and ${ }^{3} \mathrm{He} /{ }^{4} \mathrm{He}$ ratios. Beside the noble gas concentrations, the values of ${ }^{3} \mathrm{He} /{ }^{4} \mathrm{He}$ ratios were determined in form of $\mathrm{R} / \mathrm{R}_{\mathrm{a}}$, where $\mathrm{R}$ and $\mathrm{Ra}$ refer to the ${ }^{3} \mathrm{He} /{ }^{4} \mathrm{He}$ ratio in the sample and air, respectively. Air equilibrated water samples (AEW) were measured to check the precision of the measurements.

Stable carbon isotope ratio, radiocarbon and noble gas measurements were performed at the Hertelendi Laboratory of Environmental Studies in the Institute for Nuclear Research, Hungarian Academy of Sciences, Debrecen, Hungary.

\section{Results and discussion}

\subsection{Radiocarbon and tritium}

\subsubsection{Tritium}

The average tritium concentration in precipitation is about 4-5 TU in Morocco (Fez, Morocco, GNIP database, IAEA). The measured tritium concentrations of the sampled boreholes, wells and spring varied from 0 to $3.03 \mathrm{TU}$ (see Table 2). The highest tritium values $(\mathrm{S}-01=3.03 \mathrm{TU} ; \mathrm{S}-03=2.75 \mathrm{TU} ; \mathrm{S}-02=2.34 \mathrm{TU})$ measured in the outcrop zone of the Turonian aquifer decreased in the South-Western direction along the flow path away from the outcrop zone (Hsissou et al., 1996). These data can show that modern recharge might have occurred along the northeast section of the Tadla plain (from Oued Zem, Boujad to the direction of Kasba Tadla). The samples of the lowest tritium values (S-14, S-17, S-12, all $<0.5 \mathrm{TU})$ are from the confined aquifers. In addition, it can be observed that deeper samples have lower tritium concentration. Waters from a confined aquifer with a tritium concentration over 1 TU suggest a mixing between old and recent water (Bouchaou et al., 2009).

\subsubsection{Radiocarbon age determination}

To calculate the apparent age of the groundwater, the following equation was applied:

$$
t=8267 \ln \left(A_{0} / A_{t}\right)
$$

where $t$ is the radiocarbon age, $A_{0}$ is the initial and $A_{t}$ is the measured activity.

A preliminary identification of flow paths was carried out by comparison of the position of screened depth of wells and the surface altitude (Table 1), because the screened depth increases in the direction of the flow path. The ${ }^{14} \mathrm{C}$ and $\mathrm{HCO}_{3}{ }^{-}$contents decrease with depth, whereas the $\delta^{13} \mathrm{C}$ values along the flow path increase with decreasing radiocarbon and $\mathrm{HCO}_{3}{ }^{-}$content (Figs. 1 and 2). The $\delta^{13} \mathrm{C}$ values of samples from shallow groundwater reflect the $\delta^{13} \mathrm{C}$ values of $\mathrm{CO}_{2}$ of the soil zone. The $\mathrm{pH}$ slightly decreases along the flow path. In addition to the $\mathrm{CO}_{2}$ content of the soil zone, additional $\mathrm{CO}_{2}$ dissolution is assumed along the flow path, which can result in a decrease in $\mathrm{pH}$. Based on the ${ }^{14} \mathrm{C}$ and the $\delta{ }^{13} \mathrm{C}$ values, we can distinguish two flow lines with two recharge areas, the first one from the north and north-east (S-01, S-02, S-03, S-05, S-06, S-07, S-08, S-16) indicates more positive $\delta^{13} \mathrm{C}$ and decreasing ${ }^{14} \mathrm{C}$ content along the flow line. The other one is from the east (S-4, S-09, S-10, S-11 S-12, S-13, S-14, S-15, S-17) indicating slightly positive $\delta^{13} \mathrm{C}$ and decreasing ${ }^{14} \mathrm{C}$ content along the flow line (Fig. 2). These statements suggest 
Table 2

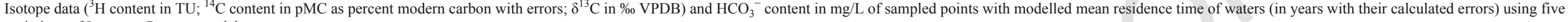
variations of Ingerson-Pearson model.

\begin{tabular}{|c|c|c|c|c|c|c|c|c|c|c|c|c|c|c|c|c|}
\hline Name & ${ }^{3} \mathrm{H}(\mathrm{TU})$ & $\begin{array}{l}{ }^{14} \mathrm{C}(\mathrm{pMC}) \\
(+/- \\
\mathrm{pMC})\end{array}$ & $\begin{array}{l}\delta^{13} \mathrm{C} \\
(\% 0 \\
\text { VPDB) }\end{array}$ & $\begin{array}{l}\mathrm{HCO}_{3}^{-} \\
(\mathrm{mg} / \mathrm{L})\end{array}$ & $\begin{array}{l}\mathrm{A}_{0}(\mathrm{pMC}) \\
\text { (Pearson) } \\
\delta^{13} \mathrm{C}_{\text {soil }}=-10 \%\end{array}$ & $\begin{array}{l}\text { Corrected } \\
\text { age }\end{array}$ & $\begin{array}{l}\mathrm{A}_{0}(\mathrm{pMC}) \\
\text { (Pearson) } \\
\delta^{13} \mathrm{C}_{\text {soil }}=-16 \%\end{array}$ & $\begin{array}{l}\text { Corrected } \\
\text { age }\end{array}$ & $\begin{array}{l}\mathrm{A}_{0}(\mathrm{pMC}) \\
(\text { Pearson) } \\
\delta^{13} \mathrm{C}_{\text {soil }}=-12 \%\end{array}$ & $\begin{array}{l}\text { Corrected } \\
\text { age }\end{array}$ & $\begin{array}{l}\mathrm{A}_{0}(\mathrm{pMC}) \\
\text { (Pearson) } \\
\delta^{13} \mathrm{C}_{\text {soil }}=-12 \% 0\end{array}$ & $\begin{array}{l}\text { Corrected } \\
\text { age }\end{array}$ & $\begin{array}{l}\mathrm{A}_{0}(\mathrm{pMC}) \\
(\mathrm{pH}=7.3) \\
\delta^{13} \mathrm{C}_{\text {soil }}=-16.4 \% 0\end{array}$ & $\begin{array}{l}\text { Corrected } \\
\text { age }\end{array}$ & $\begin{array}{l}\text { Average of } \\
\text { the } \\
\text { calculated } \\
\text { ages }\end{array}$ & $\begin{array}{l}\text { Standard } \\
\text { deviation of the } \\
\text { calculated ages }\end{array}$ \\
\hline & & & & & $\left(\mathrm{A}_{\text {soil }}=100 \mathrm{pMC}\right)$ & & $\left(\mathrm{A}_{\text {soil }}=100 \mathrm{pMC}\right)$ & & $\left(\mathrm{A}_{\text {soil }}=100 \mathrm{pMC}\right)$ & & $\left(\mathrm{A}_{\text {soil }}=90 \mathrm{pMC}\right)$ & & $\left(\mathrm{A}_{\text {soil }}=100 \mathrm{pMC}\right)$ & $\begin{array}{l}\text { (based on } \\
\mathrm{pH} \\
\text { correction) }\end{array}$ & & \\
\hline S-01 & $\begin{array}{l}3.03 \\
( \pm 0.29)\end{array}$ & $\begin{array}{l}91.44 \\
( \pm 0.28)\end{array}$ & -12.33 & 408.7 & 123.3 & $\begin{array}{l}2471 \\
( \pm 1706)\end{array}$ & 77.1 & $\begin{array}{l}-1414 \\
( \pm 1115)\end{array}$ & 102.8 & $\begin{array}{l}964 \\
( \pm 1440)\end{array}$ & 92.5 & $\begin{array}{l}93 \\
( \pm 1454)\end{array}$ & 75.2 & $\begin{array}{l}-1618 \\
( \pm 1092)\end{array}$ & 83 & 1525 \\
\hline S-02 & $\begin{array}{l}2.34 \\
( \pm 0.22)\end{array}$ & $\begin{array}{l}84.05 \\
( \pm 0.28)\end{array}$ & -11.37 & 396.5 & 113.7 & $\begin{array}{l}2498 \\
( \pm 1706)\end{array}$ & 71.1 & $\begin{array}{c}-1388 \\
( \pm 1116)\end{array}$ & 94.8 & $\begin{array}{l}991 \\
( \pm 1441)\end{array}$ & 85.3 & $\begin{array}{l}120 \\
( \pm 1454)\end{array}$ & 69.3 & $\begin{array}{l}-1592 \\
( \pm 1092)\end{array}$ & 105 & 1525 \\
\hline S- -03 & $\begin{array}{l}2.75 \\
( \pm 0.24)\end{array}$ & $\begin{array}{c}95.84 \\
( \pm 0.29)\end{array}$ & -11.99 & 396.5 & 119.9 & $\begin{array}{l}1852 \\
( \pm 1706)\end{array}$ & 74.9 & $\begin{array}{l}-2034 \\
( \pm 1115)\end{array}$ & 99.9 & $\begin{array}{l}344 \\
( \pm 1440)\end{array}$ & 89.9 & $\begin{array}{l}-527 \\
( \pm 1454)\end{array}$ & 73.1 & $\begin{array}{l}-2238 \\
( \pm 1092)\end{array}$ & -434 & 1539 \\
\hline S-04 & $\begin{array}{l}1.01 \\
( \pm 0.2)\end{array}$ & $\begin{array}{l}88.5 \\
( \pm 0.29)\end{array}$ & -8.92 & - & 89.2 & 65 & 55.8 & $\begin{array}{l}-3820 \\
( \pm 1117)\end{array}$ & 74.3 & $\begin{array}{l}-1442 \\
( \pm 1442)\end{array}$ & 66.9 & $\begin{array}{l}-2313 \\
( \pm 1456)\end{array}$ & 54.4 & $\begin{array}{l}-4024 \\
( \pm 1094)\end{array}$ & -1922 & 1791 \\
\hline S-05 & $\begin{array}{l}1.24 \\
( \pm 0.22)\end{array}$ & $\begin{array}{c}90.91 \\
( \pm 0.29)\end{array}$ & -9.86 & - & 98.6 & $\begin{array}{l}735 \\
( \pm 1706)\end{array}$ & 61.6 & $\begin{array}{c}-3150 \\
( \pm 1116)\end{array}$ & 82.2 & $\begin{array}{l}-772 \\
( \pm 1441)\end{array}$ & 74.0 & $\begin{array}{c}-1643 \\
( \pm 1455)\end{array}$ & 60.1 & $\begin{array}{c}-3354 \\
( \pm 1093)\end{array}$ & -1364 & 1664 \\
\hline S-06 & $\begin{array}{l}0.96 \\
( \pm 0.18)\end{array}$ & $\begin{array}{c}76.31 \\
( \pm 0.24)\end{array}$ & -10.94 & 292.8 & 109.4 & $\begin{array}{l}2978 \\
( \pm 1706)\end{array}$ & 68.4 & $\begin{array}{l}-908 \\
( \pm 1116)\end{array}$ & 91.2 & $\begin{array}{l}1471 \\
( \pm 1441)\end{array}$ & 82.1 & $\begin{array}{l}600 \\
( \pm 1454)\end{array}$ & 66.7 & $\begin{array}{l}-1112 \\
( \pm 1092)\end{array}$ & 505 & 1544 \\
\hline S-07 & $\begin{array}{l}0.45 \\
( \pm 0.17)\end{array}$ & $\begin{array}{l}53.81 \\
( \pm 0.18)\end{array}$ & -9.22 & 323.3 & 92.2 & $\begin{array}{l}4452 \\
( \pm 1707)\end{array}$ & 57.6 & $\begin{array}{l}566 \\
( \pm 1117)\end{array}$ & 76.8 & $\begin{array}{l}2944 \\
( \pm 1441)\end{array}$ & 69.2 & $\begin{array}{l}2073 \\
( \pm 1455)\end{array}$ & 56.2 & $\begin{array}{l}362 \\
( \pm 1094)\end{array}$ & 1733 & 1745 \\
\hline S- -08 & $\begin{array}{l}0.03 \\
( \pm 0.17)\end{array}$ & $\begin{array}{c}52.29 \\
( \pm 0.18)\end{array}$ & -8.23 & 329.4 & 82.3 & $\begin{array}{l}3749 \\
( \pm 1707)\end{array}$ & 51.4 & $\begin{array}{l}-136 \\
( \pm 1118)\end{array}$ & 68.6 & $\begin{array}{l}2242 \\
( \pm 1442)\end{array}$ & 61.7 & $\begin{array}{l}1371 \\
( \pm 1456)\end{array}$ & 50.2 & $\begin{array}{l}-340 \\
( \pm 1095)\end{array}$ & 1148 & 1624 \\
\hline S-09 & $\begin{array}{l}0.85 \\
( \pm 0.18)\end{array}$ & $\begin{array}{l}87.69 \\
( \pm 0.29)\end{array}$ & -9.32 & 367.3 & 93.2 & $\begin{array}{l}504 \\
( \pm 1707)\end{array}$ & 58.3 & $\begin{array}{l}-3382 \\
( \pm 1117)\end{array}$ & 77.7 & $\begin{array}{l}-1003 \\
( \pm 1441)\end{array}$ & 69.9 & $\begin{array}{l}-1874 \\
( \pm 1455)\end{array}$ & 56.8 & $\begin{array}{c}-3586 \\
( \pm 1094)\end{array}$ & -1557 & 1704 \\
\hline S-10 & $\begin{array}{l}0.66 \\
( \pm 0.17)\end{array}$ & $\begin{array}{l}21.6 \\
( \pm 0.14)\end{array}$ & -7.63 & 341.7 & 76.3 & $\begin{array}{c}10,432 \\
( \pm 1708)\end{array}$ & 47.7 & $\begin{array}{l}6547 \\
( \pm 1119)\end{array}$ & 63.6 & $\begin{array}{l}8925 \\
( \pm 1444)\end{array}$ & 57.2 & $\begin{array}{l}8054 \\
( \pm 1457)\end{array}$ & 46.5 & $\begin{array}{l}6343 \\
( \pm 1096)\end{array}$ & 6717 & 3626 \\
\hline S-11 & $\begin{array}{l}1.13 \\
( \pm 0.19)\end{array}$ & $\begin{array}{c}59.16 \\
( \pm 0.2)\end{array}$ & -10.13 & 341.6 & 101.3 & $\begin{array}{l}4446 \\
( \pm 1706)\end{array}$ & 63.3 & $\begin{array}{l}561 \\
( \pm 1116)\end{array}$ & 84.4 & $\begin{array}{l}2939 \\
( \pm 1441)\end{array}$ & 76.0 & $\begin{array}{l}2068 \\
( \pm 1455)\end{array}$ & 61.8 & $\begin{array}{l}357 \\
( \pm 1093)\end{array}$ & 1728 & 1743 \\
\hline S-12 & $\begin{array}{l}0.33 \\
( \pm 0.13)\end{array}$ & $\begin{array}{l}78.04 \\
( \pm 0.27)\end{array}$ & -9.22 & 352.1 & 92.2 & $\begin{array}{l}2512 \\
( \pm 1707)\end{array}$ & 57.6 & $\begin{array}{l}-1373 \\
( \pm 1117)\end{array}$ & 76.8 & $\begin{array}{l}1005 \\
( \pm 1442)\end{array}$ & 69.2 & $\begin{array}{l}134 \\
( \pm 1455)\end{array}$ & 56.2 & $\begin{array}{l}-1578 \\
( \pm 1094)\end{array}$ & 117 & 1525 \\
\hline S-13 & $\begin{array}{l}1.26 \\
( \pm 0.17)\end{array}$ & $\begin{array}{l}64.71 \\
( \pm 0.21)\end{array}$ & -9.43 & 378.2 & 94.3 & $\begin{array}{l}3113 \\
( \pm 1707)\end{array}$ & 58.9 & $\begin{array}{l}-772 \\
( \pm 1117)\end{array}$ & 78.6 & $\begin{array}{l}1606 \\
( \pm 1441)\end{array}$ & 70.7 & $\begin{array}{l}735 \\
( \pm 1455)\end{array}$ & 57.5 & $\begin{array}{l}-977 \\
( \pm 1093)\end{array}$ & 617 & 1554 \\
\hline S-14 & $<0$ & $\begin{array}{c}61.32 \\
( \pm 0.2)\end{array}$ & -8.82 & 366.0 & 88.2 & $\begin{array}{l}3005 \\
( \pm 1707)\end{array}$ & 55.1 & $\begin{array}{l}-880 \\
( \pm 1117)\end{array}$ & 73.5 & $\begin{array}{l}1498 \\
( \pm 1442)\end{array}$ & 66.2 & $\begin{array}{l}627 \\
( \pm 1456)\end{array}$ & 53.8 & $\begin{array}{l}-1085 \\
( \pm 1094)\end{array}$ & 527 & 1546 \\
\hline S-15 & $\begin{array}{l}0.71 \\
( \pm 0.21)\end{array}$ & $\begin{array}{c}19.14 \\
( \pm 0.09)\end{array}$ & -8.19 & 323.3 & 81.9 & $\begin{array}{l}12,017 \\
( \pm 1708)\end{array}$ & 51.2 & $\begin{array}{l}8132 \\
( \pm 1118)\end{array}$ & 68.3 & $\begin{array}{l}10,510 \\
( \pm 1442)\end{array}$ & 61.4 & $\begin{array}{l}9639 \\
( \pm 1456)\end{array}$ & 49.9 & $\begin{array}{l}7928 \\
( \pm 1095)\end{array}$ & 8038 & 4222 \\
\hline S-16 & $\begin{array}{l}0.55 \\
( \pm 0.18)\end{array}$ & $\begin{array}{l}42.94 \\
( \pm 0.15)\end{array}$ & -7.87 & 335.5 & 78.7 & $\begin{array}{l}5008 \\
( \pm 1708)\end{array}$ & 49.2 & $\begin{array}{l}1123 \\
( \pm 1118)\end{array}$ & 65.6 & $\begin{array}{l}3501 \\
( \pm 1443)\end{array}$ & 59.0 & $\begin{array}{l}2630 \\
( \pm 1456)\end{array}$ & 48.0 & $\begin{array}{l}919 \\
( \pm 1095)\end{array}$ & 2197 & 1866 \\
\hline S-17 & $\begin{array}{l}0.01 \\
( \pm 0.18)\end{array}$ & $\begin{array}{l}24.89 \\
( \pm 0.11)\end{array}$ & -8.31 & 335.5 & 83.1 & $\begin{array}{l}9966 \\
( \pm 1708)\end{array}$ & 51.9 & $\begin{array}{l}6081 \\
( \pm 1118)\end{array}$ & 69.3 & $\begin{array}{l}8459 \\
( \pm 1442)\end{array}$ & 62.3 & $\begin{array}{l}7588 \\
( \pm 1456)\end{array}$ & 50.7 & $\begin{array}{l}5877 \\
( \pm 1095)\end{array}$ & 6328 & 3455 \\
\hline
\end{tabular}



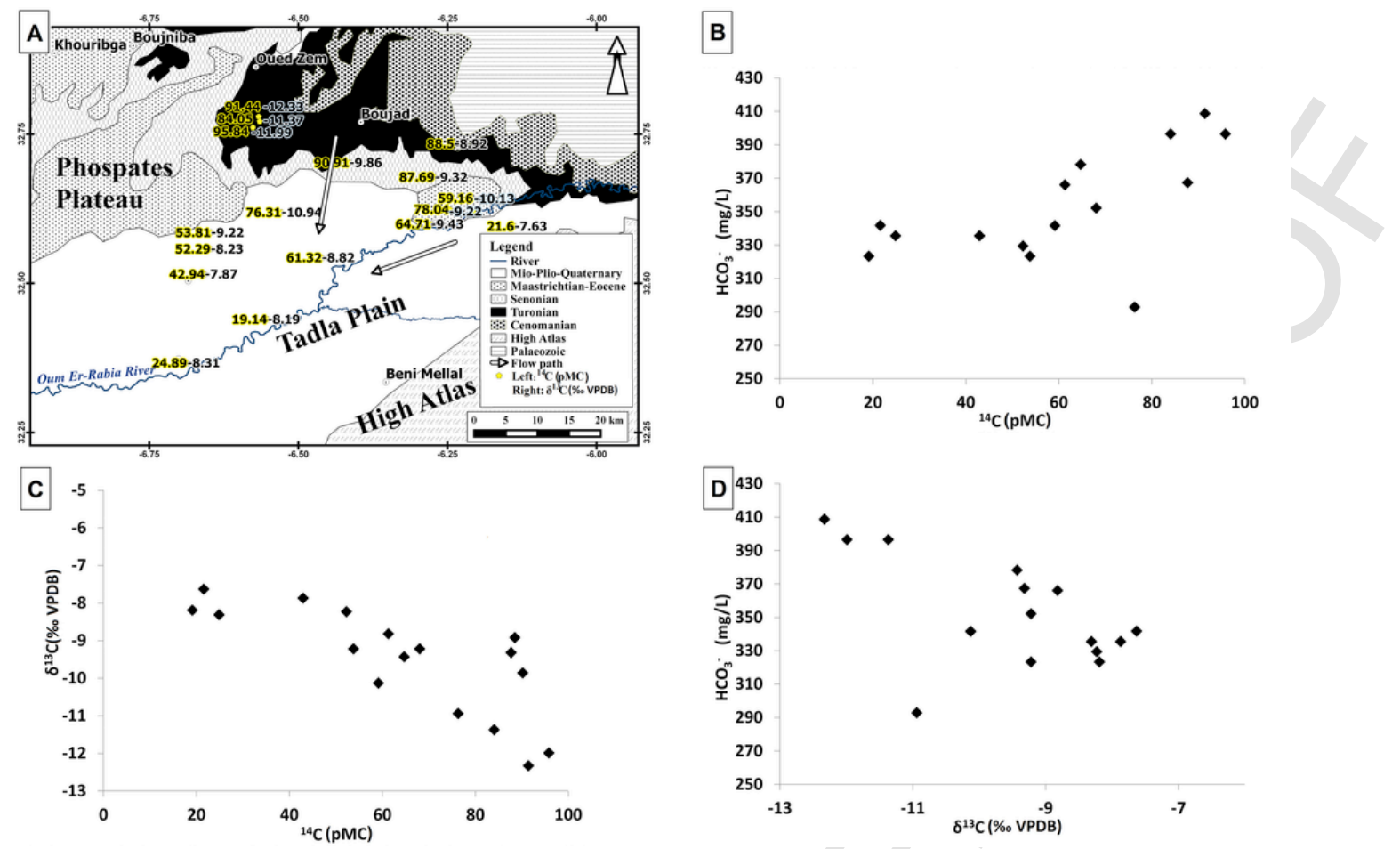

Fig. 2. A: Map of the Tadla basin plotted with the label of ${ }^{14} \mathrm{C}$ content in $\mathrm{pMC}$ (left) and $\delta^{13} \mathrm{C}\left(\%\right.$ VPDB) (right); $\mathrm{B}: \mathrm{HCO}_{3}{ }^{-}$content (mg/L) content plotted against ${ }^{14} \mathrm{C}$ content (pMC); $\mathrm{C}: \delta^{13} \mathrm{C}\left(\%\right.$ VPDB) plotted against ${ }^{14} \mathrm{C}$ content (pMC); D: $\mathrm{HCO}_{3}^{-}(\mathrm{mg} / \mathrm{L})$ content plotted against ${ }^{13} \mathrm{C}(\%$ VPDB).

that the Turonian aquifer is a complex unified system, where the variables behave similarly.

Groundwater radiocarbon ages using different versions of Ingerson-Pearson models have been calculated. A radiocarbon age was adopted to take into account the calcite and dolomite dissolutions lowering the ${ }^{14} \mathrm{C}$ content in DIC. According to Ingerson and Pearson (1964), this dilution factor (q) can be calculated by using the equation of $\mathrm{q}=\left(\delta^{13} \mathrm{C}_{\text {DIC }}-\delta^{13} \mathrm{C}_{\text {carb }}\right) /\left(\delta^{13} \mathrm{C}_{\text {soil }}-\delta^{13} \mathrm{C}_{\text {carb }}\right)$, where $\delta^{13} \mathrm{C}_{\text {DIC }}$ is the measured $\delta^{13} \mathrm{C}$ in groundwater and $\delta^{13} \mathrm{C}_{\text {carb }}$ is $\delta^{13} \mathrm{C}$ of the dissolved carbonate. The initial values are $0 \%$ VPDB for $\delta^{13} \mathrm{C}_{\text {carb. The }} \delta^{13} \mathrm{C}_{\text {soil }}$ means the $\delta^{13} \mathrm{C}$ value from the literature of the $\mathrm{CO}_{2}$ of soil, which depends on the plants: $\mathrm{C}_{3}$ plants are assumed between $-23 \%$ and $-27 \%$ VPDB, and $\mathrm{C}_{4}$ plants $-10 \%$ and $-16 \%$ VPDB. The area of the outcrop zone covered with grass species (Jones et al., 2013) which are generally $\mathrm{C}_{4}$ plants. The measured $\delta^{13} \mathrm{C}$ values of DIC are in the range of $-12.3 \%$ and $-7.6 \%$ with no value under $-12.3 \%$ VPDB, not even in the recharge area (Table 2). This also indicates that the vegetation in the recharge area is dominated by $\mathrm{C}_{4}$ plants. Therefore, we calculated the radiocarbon ages with an average $\delta^{13} \mathrm{C}_{\text {soil }}$ value of $-12 \%$ VPDB ( Clark and Fritz, 1997) and with assumed maximum and minimum $\delta^{13} \mathrm{C}_{\text {soil }}$ values of $-10 \%$ and $-16 \%$ VPDB. The dissolved carbonate is assumed to originate from soil air and carbonate minerals of the aquifer with soil air $\delta^{13} \mathrm{C}$ of $-12 \%$ VPDB and ${ }^{14} \mathrm{C}$ of $100 \mathrm{pMC}$. The $\delta^{13} \mathrm{C}$ and ${ }^{14} \mathrm{C}$ of carbonate mineral are estimated to be $0 \%$ VPDB and of $0 \mathrm{pMC}$, respectively (Pearson and Hanshaw, 1970). The initial radiocarbon content of the samples was corrected against soil and host formation, as it is mixed between soil derived DIC and the carbonate rock dissolution in a closed system.

Some studies have indicated that the vegetation of other parts of the Tadla basin (besides the recharge outcrop area) contains dominantly $\mathrm{C}_{3}$ plants (Bouchaou et al., 2009; Rhazi et al., 2009). Therefore, the radiocarbon age for $\mathrm{C}_{3}$ plants was also calculated with an average $\delta^{13} \mathrm{C}_{\text {soil }}$ value of $-23 \%$ VPDB, but with an enrichment factor which based on that fact that there is an equilibrium exchange between soil $\mathrm{CO}_{2}$ and DIC at increasing $\mathrm{pH}$. The soil became enriched in ${ }^{13} \mathrm{C}$, and therefore an extra enrichment factor $\varepsilon^{13} \mathrm{C}_{\mathrm{DIC}-\mathrm{CO} 2 \text { (soil) was added. }}$ As a result, the dilution factor $(\mathrm{q})$ can be calculated from the equation $\mathrm{q}=\left(\delta^{13} \mathrm{C}_{\text {DIC }}-\delta^{13} \mathrm{C}_{\text {carb }}\right) /\left(\left(\delta^{13} \mathrm{C}_{\text {soil }}+\varepsilon^{13} \mathrm{C}_{\text {DIC-CO2(soil) }}\right)-\delta^{13} \mathrm{C}_{\text {carb }}\right)$, where the $\varepsilon^{13} \mathrm{C}_{\text {DIC-CO2(soil) }}$ is 6,6 at $\mathrm{pH} 7.3$ (average $\mathrm{pH}$ of the wells) following the $\delta{ }^{13} \mathrm{C}$ mixing model Pearson (1965) and Pearson and Hanshaw (1970) for $\delta^{13} \mathrm{C}$ correction. The corrected ages are in Table 2 .

To investigate the outcrop zone of the aquifer, the recent water can be identified from the tritium data. By using these datasets, the initial radiocarbon activity can be estimated if those wells in the recharge area, where tritium content is above $2 \mathrm{TU}$, are considered to be recent water. Hence, we can determine the initial radiocarbon activity with the average radiocarbon data of these wells. There are three wells above $2 \mathrm{TU}$ with an average ${ }^{14} \mathrm{C}$ of $90 \mathrm{pMC}$. Radiocarbon ages were therefore calculated from $\mathrm{A}_{\mathrm{o}}=90 \mathrm{pMC}$ with the assumed $\delta^{13} \mathrm{C}_{\text {soil }}$ value of $-12 \%$ can be found in Table 2 .

Finally, five different age models were used in order to gain a complete picture of groundwater residence time (Table 2). Three Pearson models with the $\delta{ }^{13} \mathrm{C}$ and ${ }^{14} \mathrm{C}$ of carbonate mineral are estimated with $0 \%$ VPDB and of $0 \mathrm{pMC}$ and $100 \mathrm{pMC}$ for $\mathrm{A}_{0}$; with a $\delta^{13} \mathrm{C}_{\text {soil }}$ value of $-12 \%$ VPDB and thirdly, with $\delta^{13} \mathrm{C}_{\text {soil }}$ of $-10 \%$ and $-16 \%$ VPDB. In addition one variation of Pearson's model was used with a $\delta^{13} \mathrm{C}_{\text {soil }}$ value of $-12 \%$ VPDB and $90 \mathrm{pMC}$ for $\mathrm{A}_{0}$ another variation which based on an extra enrichment factor. We found that the model with 100 pMC for $A_{0}$ and with a $\delta^{13} C_{\text {soil }}$ value of $-12 \%$ VPDB seems to provide the most acceptable and reliable ages.

The error propagation of the corrected ages was derived from the errors of the independent elements in the equitation of dilution factor. The error of initial radiocarbon activity of $5 \mathrm{pMC}$ was arbitrarily based on the plausible initial value. The errors of measured radiocarbon content and $\delta^{13} \mathrm{C}$ values of DIC are the measurement errors. The 
$\delta^{13} \mathrm{C}_{\text {soil }}$ has an error of $2 \%$ VPDB based on the estimations of the vegetation which can vary between $-23 \%$ and $-27 \%$ or $-10 \%$ and $-16 \%$ VPDB. The corrected ages are reported with one sigma error. The overall minimum error of the calculated ages is $\pm 1090 \mathrm{yr}$ while the maximum error is $\pm 1700 \mathrm{yr}$. The error of the calculated radiocarbon ages is the standard deviation of the calculated ages.

We conclude that the corrected radiocarbon ages are between 0 and 10,000 years. These ages are based on two assumed initial activities ( 90 and $100 \mathrm{pMC}$ ) and indicate that the recharge of most of these waters occurred in the Holocene. There are only few wells with old waters (S-10; S-15; S17) which might have been recharged during the Late Pleistocene. There are four wells near the recharge area, which are the same with the work of Bouchaou et al. (2009): S-05-TD18; S-06-TD20; S-07-TD22; S-05-TD9, where S refers to our study, while TD refers to the numbering used by Bouchahou. To compare our results with Bouchaou and the wells in this study, we can conclude that although the two research areas do not fully overlap each other, however, we can observe that water up to $20,000 \mathrm{yr}$ old can be found in the direction of the flow path on the Phosphate Plateau, as reported by Bouchaou et al. (2009).

\subsection{Noble gas temperatures}

The noble gas concentrations and helium isotope ratios were measured in 10 samples shown in Table 3. In several samples (S-05, S-14, S-09, S-06), high neon concentrations indicate sampling artefacts, however, we can confirm by a chi-square test that this does not affect the interpretation of the results significantly. Concentrations of $\mathrm{Ne}, \mathrm{Ar}, \mathrm{Kr}$ and $\mathrm{Xe}$ in groundwater are derived from the atmosphere and were used for determining the temperature at the water table at the time of recharge. These recharge temperatures (usually called the noble gas temperature, NGT) were calculated from the concentrations of $\mathrm{Ne}, \mathrm{Ar}, \mathrm{Kr}$, and $\mathrm{Xe}$ after correcting for excess air formation, following the closed system equilibration model of gas partitioning (Aeschbach-Hertig et al., 1999). The uncertainty of the noble gas temperature determination is between 0.3 and $4.48^{\circ} \mathrm{C}$ in case of air contamination, but less than $1{ }^{\circ} \mathrm{C}$ for uncontaminated samples. The precision of the calculation is adequate, but the uncertainty of the NGTs is high.

The NGT of the samples are in the range between $19.9{ }^{\circ} \mathrm{C}(\mathrm{S}-13$; $\mathrm{S}-16)$ and $31.1^{\circ} \mathrm{C}(\mathrm{S}-09)$ (Table 3) This is in agreement with present mean annual air temperature of $19^{\circ} \mathrm{C}$ at $2 \mathrm{~m}$ above the surface (GeoModel Solar2010-2015), however the average of the NGTs is slightly higher. The noble gas temperature generally shows the mean annual soil temperature which may be $2-3{ }^{\circ} \mathrm{C}$ higher than the annual air temperature (Stute et al., 1995). The area studied belongs to a recent thermic soil temperature region, with the average soil tempera- ture higher than $15^{\circ} \mathrm{C}$ but lower than $22^{\circ} \mathrm{C}$, and with a difference between mean summer and winter soil temperatures higher than $5^{\circ} \mathrm{C}$ (Jones et al., 2013). The samples from the recharge area (S-01, S-03, S-05 and S-09) show an average noble gas temperature of $27.4{ }^{\circ} \mathrm{C}$ $\left( \pm 2.9^{\circ} \mathrm{C}\right)$. This value is much higher than recent surface temperature for the recharge area at the elevation of 400-600 $\mathrm{m}$ a.s.1. The samples (S-08; S-10; S-13; S-14; S-16) further of the recharge area in the confined part provide an average NGT of about $21.9^{\circ} \mathrm{C}\left( \pm 1.4^{\circ} \mathrm{C}\right)$. This latter value agrees very well with recent mean annual air temperatures of the Tadla basin. Since groundwater ages indicate Holocene recharge throughout the whole area investigated, we can use this to obtain a palaeotemperature record for the last ten thousand years (see Fig. 3).

The preservation of climatic signatures in a groundwater system should be connected to particular hydrodynamic conditions (Stute and Schlosser, 1993). Although the estimated radiocarbon ages show that these investigated waters recharged during the Holocene, these data also indicate the existence of palaeowater of the Turonian aquifer in the south-west area of the basin based on the increasing water mean residence time along the flow path. For an accurate palaeotemperature reconstruction, further sampling is needed in the direction of the flow path on the western part of the basin to the direction of El Borouj.

\subsection{Stable isotopes: ${ }^{18} \mathrm{O}$ and ${ }^{2} \mathrm{H}$}

Table 1 shows all the results obtained in the field as well as in the laboratory for stable isotopes. The measured $\delta^{18} \mathrm{O}$ and $\delta^{2} \mathrm{H}$ valued are plotted in Fig. 4 and are compared to the global and local meteoric water line (GMWL, Craig, 1961). The local meteoric water line (LMWL) is given by the following equation: $\delta^{2} \mathrm{H}=8 \times \delta^{18} \mathrm{O}+13$ (Bouchaou et al., 2009). The water stable isotope data cover a range from $-7.10 \%$ to $-5.14 \%$ or $\delta^{18} \mathrm{O}$, and from $-44.3 \%$ o to $-30.8 \%$ for $\delta^{2} \mathrm{H}$ (Table 1 .). The results show a very good agreement to the local meteoric water line, and confirms their meteoric origin. This suggests that the samples usually contain freshwater and indicates that isotope exchange with the host rock within the aquifer is of minor importance.

Bouchaou et al. (2009) has argued that stable isotope compositions of the groundwater samples are composed of two groups. The unconfined and confined parts of the aquifer provide different stable isotope signatures. Similarly, according to the measured isotopic composition of the sampled boreholes, wells and springs, two different groups can be distinguished. The first group with heavier isotopic composition belongs to the unconfined aquifer in the northern part of the area (the area of Boujad), while the second group is characterised by lighter isotopic composition in the north-eastern to the south-western part of the basin (to the North from Kasba Tadla) (Fig. 1). These

Table 3

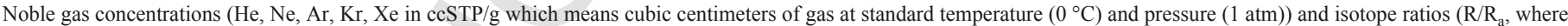

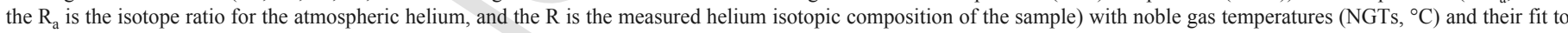
the CE-model.

\begin{tabular}{|c|c|c|c|c|c|c|c|c|c|c|}
\hline Name & Type & $\mathrm{He}(\mathrm{ccSTP} / \mathrm{g})$ & $\mathrm{Ne}(\operatorname{ccSTP} / g)$ & $\operatorname{Ar}(\operatorname{ccSTP} / g)$ & $\mathrm{Kr}(\mathrm{ccSTP} / \mathrm{g})$ & $\mathrm{Xe}(\mathrm{ccSTP} / \mathrm{g})$ & $\mathrm{R} / \mathrm{Ra}$ & $\mathrm{NGT}\left({ }^{\circ} \mathrm{C}\right)$ & $X^{2}$ & $\mathrm{p}(\%)$ \\
\hline S-01 & Well & $6.10 \mathrm{E}-08$ & $2.07 \mathrm{E}-07$ & $3.06 \mathrm{E}-04$ & $6.32 \mathrm{E}-08$ & 8.03E-09 & 0.94 & $28.4( \pm 2.2)$ & 0.04 & 84.7 \\
\hline S-03 & Well & $3.03 \mathrm{E}-07$ & $7.77 \mathrm{E}-07$ & $6.74 \mathrm{E}-04$ & $1.10 \mathrm{E}-07$ & $1.21 \mathrm{E}-08$ & 0.99 & $24.3( \pm 1.4)$ & 0.35 & 55.4 \\
\hline S-05 & Borehole & $1.12 \mathrm{E}-06$ & $2.88 \mathrm{E}-06$ & $1.82 \mathrm{E}-03$ & $2.45 \mathrm{E}-07$ & $2.25 \mathrm{E}-08$ & 0.95 & $26.0( \pm 4.4)$ & 0.73 & 39.4 \\
\hline S-06 & Borehole & 7.05E-08 & $8.58 \mathrm{E}-07$ & $5.78 \mathrm{E}-04$ & 9.32E-08 & $1.02 \mathrm{E}-08$ & 0.95 & $30.3( \pm 4.5)$ & 3.86 & 5 \\
\hline S- 08 & Borehole & 5.97E-08 & $1.89 \mathrm{E}-07$ & $2.90 \mathrm{E}-04$ & $6.31 \mathrm{E}-08$ & $8.22 \mathrm{E}-09$ & 0.92 & $23.2( \pm 0,9)$ & 0.61 & 43.5 \\
\hline S-09 & Borehole & $3.60 \mathrm{E}-07$ & $9.65 \mathrm{E}-07$ & 7.72E-04 & $1.17 \mathrm{E}-07$ & $1.21 \mathrm{E}-08$ & 0.98 & $31.1( \pm 3.2)$ & 0.83 & 36.1 \\
\hline S-10 & Borehole & $1.39 \mathrm{E}-07$ & 4.71E-07 & 4.33E-04 & $7.96 \mathrm{E}-08$ & $9.66 \mathrm{E}-09$ & 0.95 & $23.3( \pm 0.3)$ & 0.04 & 83.9 \\
\hline S-13 & Borehole & $2.42 \mathrm{E}-07$ & $6.95 \mathrm{E}-07$ & $5.66 \mathrm{E}-04$ & $9.68 \mathrm{E}-08$ & $1.17 \mathrm{E}-08$ & 0.94 & $19.9( \pm 1.7)$ & 1.15 & 28.3 \\
\hline S-14 & Borehole & $3.73 \mathrm{E}-07$ & $1.00 \mathrm{E}-06$ & 7.10E-04 & $1.15 \mathrm{E}-07$ & $1.28 \mathrm{E}-08$ & 0.95 & $21.4( \pm 1.2)$ & 0.42 & 51.9 \\
\hline S-16 & Borehole & $5.93 \mathrm{E}-07$ & $2.04 \mathrm{E}-07$ & $3.19 \mathrm{E}-04$ & $6.88 \mathrm{E}-08$ & $9.05 \mathrm{E}-09$ & 0.41 & $21.9( \pm 0.3)$ & 0.01 & 90.6 \\
\hline
\end{tabular}



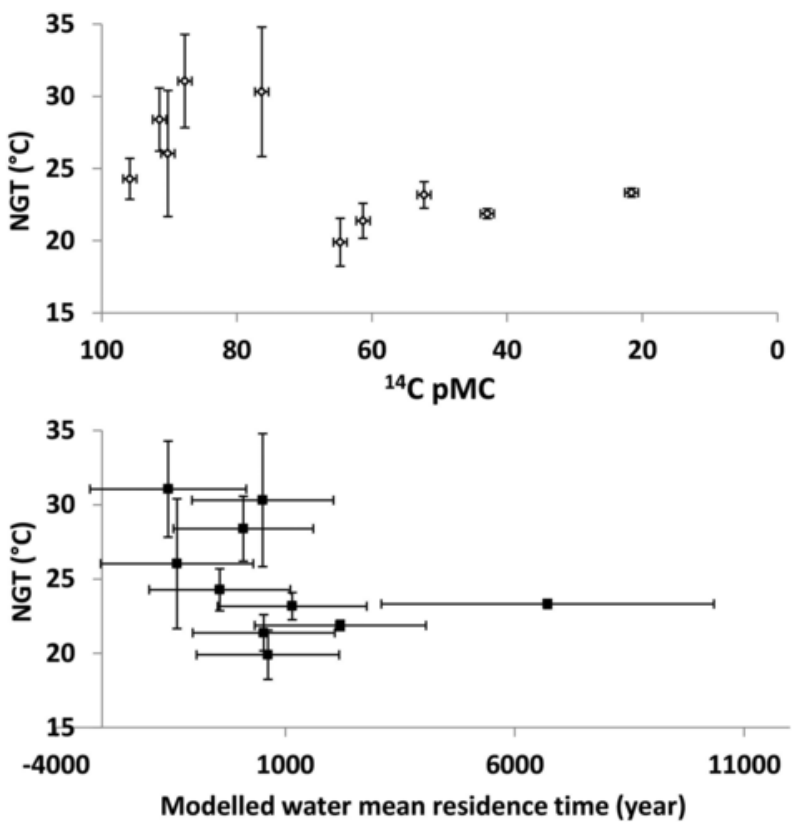

Fig. 3. Top: Variation of calculated NGT $\left({ }^{\circ} \mathrm{C}\right)$ according to ${ }^{14} \mathrm{C}$ content in pMC; Bottom: Variation of calculated NGT $\left({ }^{\circ} \mathrm{C}\right)$ according to modelled water mean residence time (year). The error of the summarized calculated radiocarbon ages described by the standard deviations of the average ages.

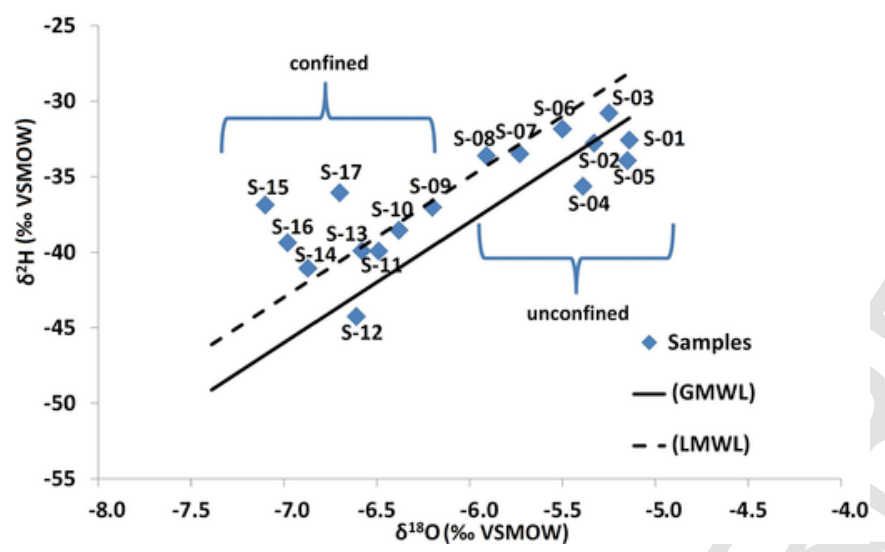

Fig. 4. $\delta^{2} \mathrm{H}$ values (\%o VSMOW) plotted against $\delta^{18} \mathrm{O}$ values (\%o VSMOW) with GMWL (Global Mean Water Line) and LMWL (Local Mean Water Line) (Craig, 1961).

latter wells and boreholes belong to the confined aquifer. Stable isotope composition is progressively depleted along the prevailing flow line (from N-NE to the area of Oulad Zmam), as if the recharge temperature had been lower for the groundwater samples from the confined aquifer. As the measured isotope values from northeast to southwest become more negative and these wells represents Holocene waters, we conclude that this pattern is not due to a change of recharge temperature, but rather that the aquifer is recharged by waters of two distinct stable isotope signatures. The flow lines from the northern part of the basin with oxygen isotope ratios around $-5.3 \%$ are affected by flow lines from the recharge area in the north-eastern part of the basin. Recharge water in this north-eastern part represents significantly lower oxygen isotope ratios between -7.0 and $-6.0 \%$.

If we correlated NGTs and the $\delta^{18} \mathrm{O}$ values, we can see that there is a weak positive connection between them (Fig. 5) and according to

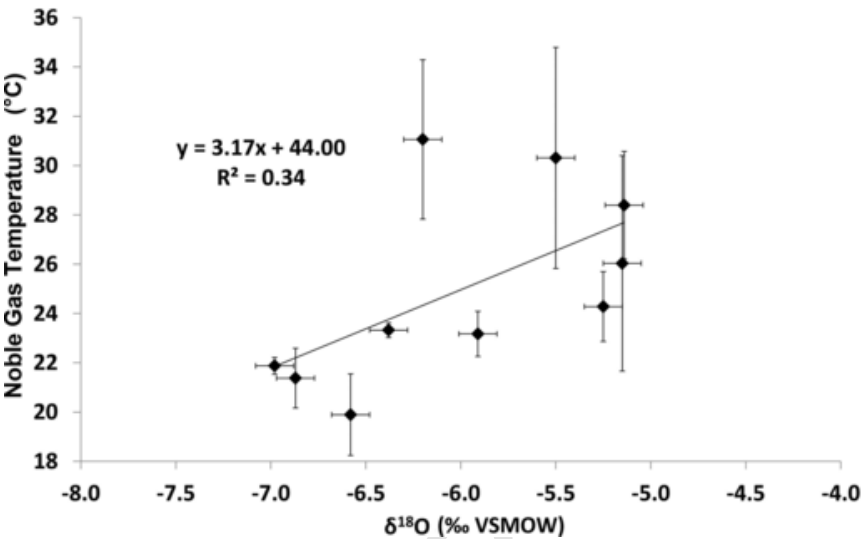

Fig. 5. Noble gas temperatures $\left({ }^{\circ} \mathrm{C}\right)$ plotted against $\delta^{18} \mathrm{O}$ values $(\%$ VSMOW) in a relation to the past climate. The high uncertainties indicate that this link to the climate negligible.

the literature, this could provide information about the past climate (Dansgaard, 1964). The groundwater samples from the unconfined part show higher NGTs than those from the confined part, and also are heavier in ${ }^{18} \mathrm{O}$ and ${ }^{2} \mathrm{H}$. Hence the heavy isotopic enrichment of $\delta^{18} \mathrm{O}$ could be connected to the warm climatic conditions and the light isotopic composition to cold conditions. However, this is a poor correlation $\left(\mathrm{R}^{2}=0.34\right)$ and the high errors of the NGTs need to be considered. Altogether these results should be linked to climate variations. We need to investigate further the role of the aquifer as "palaeothermometer", which is possible if the research area of the Turunian aquifer were extended in the direction of flow paths in the western parts of the Tadla basin (Fig. 1).

\section{Conclusion}

Isotopic analyses of sampled wells, boreholes and springs of the Turonian aquifer in the Tadla Basin show that the investigated water samples are Holocene waters. The stable isotope values confirm the direction of flow paths to south and south-west from the outcrop zone. Moving away from the recharge area, the stable isotope values became progressively depleted along the prevailing flow lines and tritium and radiocarbon concentrations decrease. This negative effect is likely caused by recharge from the north-eastern part of the recharge area with more depleted waters. The calculated noble gas temperatures of the confined part of the Turonian aquifer agree with recent mean annual air temperatures of the Tadla basin. Additionally, groundwater ages indicate Holocene recharge throughout the basin, which allowed us to obtain a palaeotemperature record for the last ten thousand year. The radiocarbon data from the research area, which show Holocene ages but with increasing mean residence times of water along the flow path confirm the existence of the palaeowater in the Turonian aquifer, in agreement with Bouchaou et al. (2009). In order to find more paleowater and construct better palaeoclimate reconstructions, it is desirable to extend the water sampling of the aquifer in the recharge area as well as in the Tadla basin, along the direction of the flow-path. Similarly, it would be important to reconstruct the paleoclimatic record in the direction of flow-paths in the area of the Phosphates Plateau (Fig. $1)$.

\section{Acknowledgements}

We are grateful for the help of Prof. A.J. Timothy Jull for the English revision and for his constructive comments. We wish to thank Irén Varsányi for her efforts and excellent suggestions. The re- 
search was partly supported by the European Union and the State of Hungary, co-financed by the European Regional Development Fund in the project of GINOP-2.3.2-15-2016-00009 'ICER'.

\section{References}

2010-2015

Geo-

Model

So-

lar,. 2010-2015 GeoModel Solar: http://solargis.info/imaps.

Abouelmagd A., Sultan M., Sturchio N.C., Soliman F., Rashed M., Ahmed M., Kehew A.E., Milewski A., Chouinard K. Paleoclimate record in the Nubian Sandstone Aquifer, Sinai Peninsula, Egypt Quaternary Research, Volume 81, Issue 1, January 2014, Pages 158-167 Aeschbach-Hertig, W., Peeters, F., Beyerle, U., Kipfer, K., 1999. Interpretation of dissolved atmospheric noble gases in natural waters. Water Resour. Res. 35, 2779-2792.

Bakari, S.S., Aagaard, P., Vogt, R.D., Ruden, F., Brennwald, M.S., Johansen, I., Gulliksen, S., 2012. Groundwater residence time and palaeorecharge conditions in the deep confined aquifers of the coastal watershed, South-East Tanzania. J. Hydrol. 466-467, 127-140.

Bouchaou, L., Michelot, J.L., Qurtobi, M., Zine, N., Gaye, C.B., Aggarwal, P.K., Marah, H., Zerouali, A., Taleb, H., Vengosh, A., 2009. Origin and residence time of groundwater in the Tadla basin (Morocco) using multiple isotopic and geochemical tools. J. Hydrol. 379, 323-338.

Clark, I.D., Fritz, P., 1997. Environmental Isotopes in Hydrogeology. Lewis Publishers. ISBN1-56670-249-6.

Craig H., Isotopic Variations in Meteoric Waters, Science. 1961 May 26;133(3465):1702-3. Dansgaard, W., 1964. Stable isotopes in precipitation. Tellus $5,461-469$.

Darling, W.G., Edmunds, W.M., Kinniburgh, D.G., Kotoub, S., 1987. Sources of recharge to the Basal Nubian Sandstone Aquifer, Butana region, Sudan. In: Isotope Techniques in Water Resources Development. International Atomic Energy Agency, Vienna, pp. 205-224. 1987.

Ettazarini, S., 2004. Incidences of water-rock interaction on natural resources characters, Oum Er-Rabia Basin (Morocco). Environ. Geol. 47, 69-75.

Ettazarini, S., 2006. Groundwater pollution risk mapping for the Eocene aquifer of the Oum Er-Rabia basin, Morocco. Environ. Geol. 51, 341-347.

Ettazarini, S., Mahmouhi, N.El, 2004. Vulnerability mapping of the Turonian limestone aquifer in the phosphates plateau (Morocco). Environ. Geol. 46, 113-117.

Fontes, J.-C., Gasse, F., Andrews, J.N., 1993. Climatic conditions of Holocene groundwater recharge in the Sahel zone of Africa. In: Isotope Techniques in the Study of Past and Current Environmental Changes in the Hydrosphere and the Atmosphere. IAEA, Vienna, pp. 231-248. 1993, IAEA-SM-329/59.

Heaton, T.H.E., Talma, A.S., Vogel, J.C., 1986. Dissolved gas paleotemperatures and $18 \mathrm{O}$ variations derived from groundwater near Uitenhage, South Africa. Quat. Res. 25, 79-88.

Hsissou, Y., Chauve, P., Mania, J., 1996. The aquifer of Turonian limestones (Tadla Basin, Morocco). Local and remote groundwater recharge from the Atlas. J. Hydrol. 183, 433-443.

Ingerson, E., Pearson Jr., F.J., 1964. Estimation of age and rate of motion of ground-water by the ${ }^{14} \mathrm{C}$ method. In: Recent Research in the Field of Hydrosphere, Atmosphere, and Nuclear Geochemistry, Maruzen, Tokyo. 263.

Jones, A., Breuning-Madsen, H., Brossard, M., Dampha, A., Deckers, J., Dewitte, O., Gallali, T., Hallett, S., Jones, R., Kilasara, M., Le Roux, P., Micheli, E., Montanarella, L., Spaargaren, O., Thiombiano, L., Van Ranst, E., Yemefack, M., Zougmoré, R. (Eds.), 2013. Soil Atlas of Africa. European Commission, Publications Office of the European Union, Luxembourg. ISBN 978-92-79-26715-4, pp: 18-19; $80-81$.

Klump, S., Grundl, T., Purtschert, R., Kipfer, R., 2008. Groundwater and climate dynamics derived from noble gas, $14 \mathrm{C}$, and stable isotope data. Geology $36,395-398$.

Kulongoski, J.T., Hilton, D.R., Selaolo, E.T., 2004. Climate variability in the Botswana Kalahari from the late Pleistocene to the present day. Geophys. Res. Lett. 31, L10204.
Marah, H., 2007. Liquid scintillation low level tritium measurement in water. Phys. Chem. News 37, 20-24.

Marah, H., Qurtobi, M., Zine, N., Zeouali, A., 2010. Improving understanding of hydrogeology in Morocco's Tadla Basin. In: IAEA Water and Environmental News, Newsletter of the Isotope Hydrology Section Issue No. 27. pp. 9-11. ISNN 1020-7120.

Misdaq, M.A., Eiharti, A., 1997. Study of the influence of the lithological and hydrogeological parameters of aquifers on the radon emanation from underground waters using solid state nuclear track detectors. J. Radioanal. Nucl. Chem. 218, 209-214

Molnár, M., Janovics, R., Major, I., Orsovszki, J., Gönczi, R., Veres, M., Leonard, A.G., Castle, S.M., Lange, T.E., Wacker, L., Hajdas, I., Jull, A.J.T., 2013a. Status report of the new AMS 14C sample preparation lab of the Hertelendi laboratory of environmental studies (Debrecen, Hungary). Radiocarbon 55, 665-676.

Molnár, M., Rinyu, L., Veres, M., Seiler, M., Wacker, L., Synal, H.-A., 2013b. EnvironMICADAS: a mini ${ }^{14} \mathrm{C}$ AMS with enhanced gas ion source interface in the Hertelendi laboratory of environmental studies (HEKAL), Hungary. Radiocarbon $55,338-344$.

Molnár, M., Hajdas, I., Janovics, R., Rinyu, L., Synal, H., Veres, M., Wacker, L., 2013c. C-14 analysis of groundwater down to the milliliter level. SCI Nucl. Instrum. Methods Phys. Res. Sect. B Beam Interact. Mater. Atoms 294, 573-576.

Palcsu, L., Major, Z., Köllö, Z., Papp, L., 2010. Using an ultrapure 4He spike in tritium measurements of environmental water samples by the $3 \mathrm{He}$-ingrowth method. Rapid Commun. Mass Spectrom. 24, 698-704

Papp, L., Palcsu, L., Major, Z., Rinyu, L., Tóth, I., 2012. A mass spectrometric line for tritium analysis of water and noble gas measurements from different water amounts in the range of microlitres and millilitres. Isotopes Environ. Health Stud. 48, 494-511.

Pearson, F.J., 1965. Use of C-13/C-12 ratios to correct radiocarbon ages of material initially diluted by limestone. In: Processing of the 6th International Conference on Radiocarbon and Tritium Dating. Pulman, Washington 357

Pearson, F.J., Hanshaw, B.B., 1970. Sources of dissolved carbonate species in groundwater and their effects on carbon - 14 dating. In: Isotope Hydrology:Vienna. pp. 271-285. IAEA (IAEA-SM-129/18).

Peel, M.C., Finlayson, B.L., McMahon, T.A., 2007. Updated world map of the Köppen-Geiger climate classification. Hydrol. Earth Syst. Sci. Discuss. EGU 4, 439-473.

Rhazi, L., Grillas, P., Rhazi, M., Aznar, J.-C., 2009. Ten-year dynamics of vegetation in Mediterranean temporary pool in western Morocco. Hydrobiologia $634,185-194$.

Rinyu, L., Molnár, M., Major, I., Nagy, T., Veres, M., Kimák, , Wacker, L., Synal, H.-A., 2013. Optimization of sealed tube graphitization method for environmental C-14 studies using MICADAS. SCI Nucl. Instrum. Methods Phys. Res. Sect. B Beam Interact. Mater. Atoms 294, 270-275.

Rozanski, K., Araguas-Araguas, L., Gonfiantini, R., 1993. Isotopic patterns in modern global precipitation. Clim. Change Cont. Isotopic Rec. Am. Geophys. Union (Geophys. Monogr. Ser.) 78, 1-36.

Rudolph, J., Rath, H.K., Sonntag, C., 1984. Noble gases and stable isotopes in 14 C-dated palaeowaters from central Europe and the Sahara. In: Isotope Hydrology. IAEA, Vienna, pp. 467-477. 1983.

Stute, M., Schlosser, P., 1993. Principles and applications of the noble gas paleothermometer. In: AGU Monograph on Climate Change in Continental Isotopic, Records, Geophysical Monograph, 78, pp. 89-100.

Stute, M., Clark, J.F., Schlosser, P., Broecker, W.S., Bonani, G., 1995. A 30,000 yr continental paleotemperature record derived from noble gases dissolved in groundwater from the San Juan Basin, New Mexico. Quat. Res. 43, 209-220.

Tammal, M., Kili, M., Gasmi, H. El, Mridekh, A., Mansouri, B.El, 2014. Modélisation multicouche du système aquifère du bassin de Tadla et le plateau des phosphates/ Modeling multi-aquifer system of Tadla basin and plateau of phosphates. Int. J. Innov. Sci. Res. 6, 172-180.

Varsányi, I., Palcsu, L., Kovács, L.O., 2011. Groundwater flow system as an archive of palaeotemperature: noble gas, radiocarbon, stable isotope and geochemical study in the Pannonian Basin, Hungary. Appl. Geochem. 26, 91-104.

Vodila, G., Palcsu, L., Futó, I., Szántó, Zs, 2011. A 9-year record of stable isotope ratios of precipitation in Eastern Hungary: implications on isotope hydrology and regional palaeoclimatology. J. Hydrol. 400, 144-153. 